\title{
Pengaruh Pajak, Mekanisme Bonus Dan Exchange Rate Terhadap Keputusan Untuk Melakukan Transfer Pricing
}

(Studi Empiris pada Perusahaan Manufaktur yang Terdaftar di Bursa Efek Indonesia Tahun 2016-2020)

\author{
Esa Agustin', Hari Stiawan ${ }^{2}$ \\ 1, 2,Program Studi Akuntansi , Fakultas Ekonomi dan Bisnis, Universitas Pamulang, Tangerang \\ selatan, Indonesia. \\ Email: ${ }^{1}$ essaagustine57@gmail.com, ${ }^{2}$ dosen01254@unpam.ac.id
}

\begin{abstract}
This research aims to provide empirical evidence of the influence of taxes, bonus mechanisms, and exchange rates on transfer pricing decisions. This study used a sample of manufacturing companies listed on the Indonesia Stock Exchange during the period 2016 to 2020. The number of companies sampled by this study was 11 sampling, the total sample of this study was 55 units of analysis. The type of research used is quantitative research. The study used purposive sampling. The data analysis in this study used regression using Eviews version 9 software. The results of this study show that taxes, bonus mechanisms, exchange rates together have an simultaneous effect on the decision to transfer pricing. Partial testing concluded that taxes had no effect on transfer pricing, bonus mechanisms had no effect on transfer pricing, and exchange rates had an effect transfer pricing.
\end{abstract}

Keywords: Taxes, Bonus Mechanisms, Exchange Rates, Transfer Pricing

\begin{abstract}
Abstrak
Penelitian ini bertujuan untuk memberikan bukti secara empiris pengaruh pajak, mekanisme bonus, dan exchange rate terhadap keputusan melakukan transfer pricing. Penelitian ini menggunakan sampel perusahaan manufaktur yang terdaftar di Bursa Efek Indonesia selama periode 2016 samapai dengan 2020. Jumlah perusahaan yang dijadikan sampel penelitian ini adalah 11 sampling, total sampel penelitian ini adalah 55 unit analisis. Jenis penelitian yang digunakan adalah penelitian Kuantitatif. Penelitian ini menggunakan purposive sampling. Analisis data dalam penelitian ini menggunakan regresi dengan menggunakan software Eviews versi 9. Hasil penelitian ini menunjukan bahwa pajak, mekanisme bonus, exchange rate bersama-sama berpengaruh secara simultan terhadap keputusan melakukan transfer pricing. Pengujian parsial menyimpulkan bahwa pajak tidak berpengaruh terhadap transfer pricing, mekanisme bonus tidak berepengaruh terhadap transfer pricing, dan exchange rate berpengaruh terhadap
\end{abstract}

\section{Kata Kunci: Pajak, Mekanisme Bonus, Exchange Rate, Transfer Pricing}

\section{PENDAHULUAN}

Transfer pricing merupakan haraga transfer atas harga jual barang, jasa, dan harta tidak berwujud kepada anak perusahaan kepada pihak yang mempunyai hubungan istimewa yang berlokasi di berbagai negara ( Astuti,2008:12 ; Refgia ,2017). Terdapat fenomena yang terjadi pada perusahaan makanan dan minuman yang melakukan penghindaran pajak melibatkan salah satu perusahaan dalam kelompok coca cola company, yaitu PT Coca Cola Indonesia. PT Coca Cola Indonesia diduga memanipulasi pajak sehingga menimbulkan kekurangan pembayaran pajak senilai Rp 49,24 miliar. Hasil penelusuran Diktorat Jendral Pajak (DJP), Kementrian Keuangan menemukan adanya pembengkakan biaya yang besar pada tahun 20022006. Beban biaya yang besar mengakibatkan pengahasilan kena pajak berkurang, sehingga 
setoran pajaknya pun menyusut. Beban biaya itu antara lain untuk iklan dari rentang waktu tahun 2002-2006 dengan total sebesar Rp 566,84miliar. Dengan kasus tersebut penilitian menganalisis bahwa praktik penghindaran pajak yang dilakukan oleh PT Coca Cola Indonesia karena mereka ingin menekan biaya pajak yang disetorkan. Cara yang dilakukan oleh PT Coca Cola Indonesia dalam melakukan penghindaran pajak yaitu transfer pricing.

Selain alasan pajak, keputusan perusahaan untuk melakukan transfer pricing juga dapat dipengaruhi oleh mekanisme bonus . mekanisme bonus adalah kompensasi tambahan atau penghargaan yang diberikan kepada pegawai kepegawaian atas keberhasilan pencapaian tujuan-tujuan yang ditargetkan oleh perusahaan. Mekanisme bonus berdasarkan laba merupakan salah satu jalan yang sering digunakan perusahaan dalam memberikan penghargaan kepada direksi atau manajer.

Hal lain yang mempengaruhi keputusan perusahaan untuk melakukan transfer pricing adalah nilai tukar (exchange rate). Dalam beberapa mata uang dimana nilai setiap mata uang terukur kepada nilai dolar akan berbeda seiring dengan perbedaan waktu. Oleh itu Exchange rate yang berbeda inilah, yang nanti akan mempengaruhi praktik transfer pricing pada perusahaan multinasional(Azizah,2014).

Terlihat bahwa hasil penelitian mengenai pengaruh pajak terhadap keputusan untuk melakukan transfer pricing dan mekanisme bonus terhadap keputusan untuk melakukan transfer pricing serta exchange rate terhadap keputusan untuk melakukan transfer pricing juga masih memberikan hasil yang tidak konsisten dari hasil penelitian sebelumnya, oleh karena itu peneliti ini tertarik untuk melakukan penelitian yang berjudul "PENGARUH PAJAK,MEKANISME BONUS DAN EXCHANGE RATE TERHADAP KEPUTUSAN UNTUK MELAKUKAN TRANSFER PRICING (StudiEmpiris Pada Perusahaan Properti Dan Real Estate Yang Terdaftar Di Bursa Efek Indonesia Tahun 2016-2020).

\section{Rumusan Masalah}

Berdasarkan latar belakang diatas, permasalahan yang diteliti dapat dirumuskan sebagai berikut :

1. Apakah pajak berpengaruh terhadap transfer pricing?

2. Apakah mekanisme bonus berpengaruh terhadap transfer pricing ?

3. Apakah exchange rate berpengaruh terhadap transfer pricing?

4. Apakah pajak, mekanisme bonus, dan exchange rate berpengaruh terhadap transfer pricing

\section{METODE PENELITIAN}

Penelitian ini merupakan jenis penelitian kuantitatif. Menurut Sugiono (2016:8) Pengertian metode kuantitaf adalah metode penelitian yang berlandaskan pada filsafat positivisme, digunakan untuk meneliti pada populasi dan sempel tertentu, pengumpulan data yang digunakan ialah instrumen penelitian, analisis data dan bersifat kuantitatif yang bertujuan untuk mengkaji hipotesis yang telah ditetapkan. Penelitian ini diambil dari laporan keuangan tahunan perusahaan manufaktur yang terdaftar dalam Bursa Efek Indonesia.

\section{Pajak (X1)}

Pajak adalah kontribusi wajib kepada negara yang terutang oleh orang pribadi atau badan yang bersifat memaksa berdasarkan Undang-undang. Pajak dalam penelitian ini diukur dengan Effective tax rate (ETR). Effective tax rate yang merupakan perbandingan tax expense dikurangi differed tax expanse dibagi dengan laba kena pajak (Yuniasih et al,2012) dalam (Wafiroh,2017). Cara mengukur ETR, yaitu dengan cara :

\section{Beban Pajak Penghasilan}

ETR $=$

Laba Sebelum Pajak 


\section{Mekanisme Bonus (X2)}

Mekanisme bonus ialah komponen perhitungan besarnya jumlah bonus yang diberikan oleh pemilik perusahaan atau para pemegang saham melalui RUPS kepada anggota direksi setiap setiap tahun apabila memperoleh laba (Suryatiningsih,2009) dalam (Wafiroh,2016).

Laba Bersih Tahun T

ITRENDLB = $X 100 \%$

\section{Laba Bersih tahun T-1}

\section{Exchange Rate (X3)}

Variabel exchange rate dapat dihitung menggunakan laba rugi selisih kurs dibagi dengan laba rugi sebelum pajak (Cahyadi dan Noviari,2018).

\section{Exchange Rate $=$}

Laba Rugi Selisih Kurs

\section{Laba Rugi Sebelum Pajak}

\section{Transfer Pricing}

Variabel dependen dalam penelitian ini adalah transfer pricing yang dilambangkan dengan Y. Transfer pricing diukur dengan menggunakan proksi rasio nilai transaksi pihak berelasi (relatedparty transaction/RPT) piutang atas total piutang.

\section{Piutang Transaksi Pihak Berelasi \\ Transfer Pricing $=$ $X 100 \%$ \\ Total Piutang}

\section{Sampel}

Pemilihan sampel salam penelitian ini menggunakan metode purposive sampling dengan kriteria sebagai berikut :

1. Penelitian ini menggunakan perusahaan manufaktur yang terdaftar di Bursa Efek Indonesia selama Tahun 2016-2020.

2. Perusahaan Manufaktur yang terdaftar di BEI yang mempublikasikanlaporan tahunan dan laopran keuangan perusahaan yang telah diaudit berturut-turut selama periode 2016-2020.

3. Perusahaan Manufaktur yang menggunakan satuan mata uang rupiah dalam laporan keuangan periode 2016-2020.

4. Perusahaan tersebut selalu melaporkan Laporan Keuangan ke Bursa Efek Indonesia dalam periode 2015-2019 secara berturut-turut dan tidak mengalami kerugian.

5. Memiliki data keuangan secara lengkap yang berkaitan dengan variabel penelitian selama periode penelitian.

\section{HASIL DAN PEMBAHASAN}

Hasil Uji Statistik Deskriptif

3.1 Hasil Uji deskriptif

\begin{tabular}{|lllll|}
\hline & Y & X1 & X2 & X3 \\
\hline Mean & 34095.67 & 24016.89 & 128687.5 & 5096.891 \\
Median & 18000.00 & 23930.00 & 113837.0 & 1178.000 \\
Maximum & 99986.00 & 42541.00 & 802061.0 & 45339.00 \\
Minimum & 102.0000 & 1242.000 & 128.0000 & 105.0000 \\
Std. Dev. & 36227.95 & 7646.294 & 102103.5 & 10011.81
\end{tabular}




\begin{tabular}{|c|c|c|c|c|}
\hline Skewness & 0.582207 & -0.140902 & 5.304235 & 2.820846 \\
\hline Kurtosis & 1.709982 & 3.926223 & 35.80786 & 10.66399 \\
\hline Jarque-Bera & 6.920845 & 2.147986 & 2724.552 & 207.5457 \\
\hline Probability & 0.031416 & 0.341642 & 0.000000 & 0.000000 \\
\hline $\begin{array}{l}\text { Sum } \\
\text { Sum }\end{array}$ & 1875262 & 1320929 & 7077815. & 280329.0 \\
\hline Dev. $\quad$ Sq & $7.09 E+10$ & $3.16 \mathrm{E}+09$ & $5.63 E+11$ & $5.41 E+09$ \\
\hline $\begin{array}{l}\text { Observatio } \\
\text { n s }\end{array}$ & 55 & 55 & 55 & 55 \\
\hline
\end{tabular}

Berdasarkan table uji statistic deskriptif diatas, dapat dijelaskan sebagai berikut:

1. Berdasarkan tabel, dari 55 data penelitian nilai Transfer Pricing (Y) terkecil (minimum) adalah 102.0000 dan nilai terbesar (maximum) adalah 99986.00. Nilai median Transfer pricing dari 55 data adalah 18000.00 dan nilai rata-rata (mean) nya adalah 34095.67.

2. Berdasarkan table diatas menunjukan Pengaruh pajak (X1) terkecil (minimum) adalah 1242.000 dan nilai terbesar (maximum) adalah 42451.00. Nilai median Pengaruh pajak (X1) dari 75 data penelitian adalah 23930.00, dengan nilai rata-rata (mean) adalah 24016.89.

3. Berdasarkan tabel, dari 55 data penelitian nilai Mekanisme Bonus (X2) terkecil (minimum) adalah 128.0000 dan nilai terbesar (maximum) adalah 802061.0. Nilai median Mekanisme Bonus dari 55 data penelitian adalah 113837.0 dengan nilai ratarata (mean) adalah 128687.5.

4. Berdasarkan tabel, dari 55 data penelitian nilai Exchange Rate (X3) terkecil (minimum) adalah 105.0000 dan nilai terbesar (maximum) adalah 45339.00. Nilai median Exchange Rate dari 55 data penelitian adalah 1178.000 dengan nilai ratarata (mean) adalah 5096.891.

\section{Pemilihan Model Regresi}

A. Uji Chow

Tabel 3.2 Hasil Uji Chow

\begin{tabular}{|llll|}
\hline $\begin{array}{l}\text { Redundant Fixed Effects Tests } \\
\text { Equation: Untitled } \\
\text { Test cross-section fixed } \\
\text { effects }\end{array}$ & & & \\
\hline Effects Test & Statistic & d.f. & Prob. \\
\hline $\begin{array}{llll}\text { Cross-section F } \\
\text { Cross-section Chi-square }\end{array}$ & $\begin{array}{l}5.502585 \\
46.807497\end{array}$ & $\begin{array}{l}(10,41) \\
10\end{array}$ & 0.0000 \\
\hline
\end{tabular}

Berdasarkan tabel 3.2 menunjukan bahwa nilai probabilitas (Prob) Cross-section Chi-square adalah $0.0000<0.05$ (ditentukan diawal tingkat signifikan atau alpha), maka H1 diterima. Sehingga model Fixed Effect lebih tepat digunakan daripada model Common Effect.

B. Uji Hausman

Tabel 3.3 Hasil Uji Chow

\begin{tabular}{|llll|}
\hline $\begin{array}{l}\text { Correlated Random Effects - Hausman Test } \\
\text { Equation: Untitled } \\
\text { Test cross-section random effects }\end{array}$ & & \\
\hline Test Summary & $\begin{array}{l}\text { Chi-Sq. } \\
\text { Statistic }\end{array}$ & Chi-Sq. d.f. & Prob. \\
\hline Cross-section random & 8.794729 & 3 & 0.0321 \\
\hline
\end{tabular}


menunjukan bahwa nilai probabilitas (Prob) Cross-section random adalah $0.0321<0.005$ (ditentukan diawal sebagai tingkat signifikan atau alpha), maka $\mathrm{H} 1$ diterima. Sehingga model Fixed Effext lebih tepat digunakan dibandingkan dengan Random Effect.

\section{Hasil Uji Asumsi Klasik}

Uji asumsi klasik dilakukan untuk mengetahui apakah model regresi memenuhi kriteria BLUE (best, linier,unbiased, dan efficient estimator) sehingga perlu dilakukan. Untuk melakukan uji asumsi klasik atas data sekunder, maka penelitian ini melakukan uji normalitas, uji multikolineritas, uji autokolerasi, dan uji heteroskedastisitas.

1. Uji Normalitas

12



Berdasarkan gambar 4.1 uji normalitas dapat diketahui bahwa nilai Probabilitas (Prob.) sebesar $0.079075>0.05$ yang artinya nilai probabilitas lebih dari 0.05 sehingga berdistribusi normal atau lolos uji normal.

\section{Uji Multikolineritas}

Uji multikolineritas bertujuan untuk mendeteksi gejala kolerasi antara variabel bebasdengan variabel bebas lainnya. Multikolinearitas dapat dilihat dari nilai Tolerance (TOL) atau metode VIF(Variance Inflation Factor). berdasarkan uji multikolinearitas dapat dilihat bahwa tidak ada nilai kolerasi antar variabel independen yang melebihi 0,90, maka dapat disimpulkan antara variabel independen terbebas masalah multikolinearitas.

\section{Uji Heterokedastisitas}

Berdasarkan hasil uji heterokedastisitas dapat dilihat bahwa nilai probabilitas dari residual variabel independent $>0.05$, maka $\mathrm{H} 1$ diterima atau dapat disimpulkan bahwa dalam penelitian ini data tidak terdapat gejala heterokedastisitas.

\section{Uji Autokolersi}

Uji autokorelasi bertujuan menguji apakah dalam suatu model regresi linear ada korelasi antar kesalahan pengganggu (residual) pada periode $t$ dengan kesalahan pada periode $t-1$ (sebelumnya).Pengujian asumsi autokorelasi dapat dilihat melalui Durbin-Watson Test.

Tabel 3.4 Uji Autokorelasi

\begin{tabular}{|llll|}
\hline F-statistic & 8.868933 & Durbin-Watson stat & 1.907387 \\
Prob(F-statistic) & 0.000000 & & \\
\hline
\end{tabular}

Berdasarkan hasil uji autokolerasi pada tabel diatas menunjukan bahwa nilai dari DurbinWatson (DW) sebesar 1.907287, pembanding menggunakan nilai signifikan $5 \%$, jumlah sampel $55(\mathrm{n})$, dan jumalah variabel independen $2(\mathrm{k}=3)$, maka ditabel Durbin-Watson akan di dapat nilai (du) 1.6815. karena nilai DW 1.907387 lebih besar dari batas (du) 1.6815dan kurang dari 4- 1.6815 (2.3185), maka dapat disimpulkan bahwa model model regresi tidak terjadi 
autokolerasi dan model regresi ini layak untuk digunakan.

\section{Uji Hipotesis}

1 Uji Koefisien Determinasi ${ }^{2}$

Tabel 3.5 Uji Koefisien Determinasi ${ }^{2}$

\begin{tabular}{|c|c|c|c|}
\hline \multicolumn{4}{|c|}{ Effects Specification } \\
\hline \multicolumn{4}{|c|}{ Cross-section fixed (dummy variables) } \\
\hline R-squared & 0.737677 & Mean dependent var & $\begin{array}{c}9.06924 \\
2\end{array}$ \\
\hline Adjusted R-squared & 0.654502 & S.D. dependent var & $\begin{array}{c}2.24052 \\
3\end{array}$ \\
\hline
\end{tabular}

Berdasarkan hasil uji Determinasi Adjusted $R^{2}$ pada tabel 4.15 diatas, besarnya nilai Adjusted R-squared adalah 0.654502. Hal ini menunjukan bahwa variabel Transfer Pricing dapat dijelaskan oleh variabel independen ( Pajak,Mekanisme Bonus, Exchange Rate) sebesar $65 \%$. Sedangkan sisanya $(100 \%-65 \%=35 \%)$ dijelaskan oleh variabel lain yang tidak disertakan dalam penelitian ini.

2 Uji Parsial ( Uji T)

Berdasarkan hasil uji t diketahui bahwa 0.05, atau, maka nilai t tabel adalah 2.00856. Hasil yang didapat berdasarkan uji t sebagai berikut:

1. Pajak terhadap Transfer Pricing

Variabel $x 1$ diperoleh $t$ hitung $-1.155503<t$ table (2.00856) dan nilai signifikan $>0.05$. Hal ini berarti variabel pajak tidak berpengaruh terhadap transfer pricing.

2. Mekanisme Bonus terhadap Transfer Pricing

Variabel $x 2$ di peroleh t hitung $0.623672<t$ table (2.00856) dan nilai signifikan > 0,05. Hal ini berarti variabel mekanisme bonus tidak berpengaruh terhadap transfer pricing .

3. Exchange Rate terhadap Transfer Pricing

Variabel X3 diperoleh t hitung $-2.481295>t$ tabel (2.00856) dan nilai signifikan $<0.05$. Hal ini berarti variabel exchange rate perpengaruh terhadap transfer pricing.

\section{Uji F ( Simultan)}

\begin{tabular}{|l|l|}
\hline F-statistic & 8.868933 \\
\hline Prob(F-statistic) & 0.000000 \\
\hline
\end{tabular}

Berdasarkan tabel analisis regresi berganda diatas, diketahui bahwa :

Variabel Pajak (X1), Mekanisme Bonus (X2), Exchange Rate (X3) diperoleh F hitung $8.868933>\mathrm{F}$ tabel 2,56 dan nilai signifikan $<0,05$ hal ini berarti variabel Pajak (X1),Mekanisme Bonus (X2), Exchange Rate (X3) berpengaruh secara simultan terhadapat Transfer Pricing .

\section{Pembahasan}

\section{Pengaruh Pajak Terhadap Transfer Pricing}

Hal ini terjadi karena didalam perusahaan beban pajak yang besar tidak memicu perusahaan untuk melakukan transfer pricing dengan harapan dapat menekan beban tersebut, Hasil penelitian ini mendukung penelitian yang dilakukan oleh (mispiyanti,2015) yang menyatakan bahwa pajak tidak berpengaruh signifikan terhadap keputusan transfer pricing. 


\section{Pengaruh Mekanisme Bonus Terhadap Transfer Pricing}

Hal ini terjadi karena ketidakkonsistenan perusahaan dalam menaikan laba dari tahun ke tahun. Selain itu bias juga karena perusahaan manufaktur memiliki mekanisme pengawasan stakeholder yang baik. Namun, hasil penelitian ini sama dengan Mispiyanti (2015) dan Pramana (2014) yang menemukan bahwa mekanisme bonus tidak berpengaruh terhadap Transfer Pricing.

\section{Pengaruh Exchange Rate Terhadap Transfer Pricing}

maka dapat disimpulkan bahwa hal ini variabel exchange rate berepngaruh terhadap Transfer Pricing. Hal ini terjadi karena besar -kecilnya exchange rate tidak mempengaruhi pertimbangan perusahaan apakah perusahaan akan memilih untuk melakukan transfer pricing atau memilih untuk tidak melakukan keputusan transfer pricing dalam perusahaan.

\section{Pengaruh Pajak, Mekanisme Bonus dan Exchange Rate Terhadap Transfer Pricing}

Berdasarkan hasil penelitian menunjukan bahwa nilai signifikasi pada variabel Pajak sebesar prob. $0.2546>0.05$. Nilai Koefisien yang dimiliki sebesar-0.449723. dan dari hasil pengujian secara parsial nilai t hitung $<\mathrm{t}$ tabel yaitu $-1.155503<2.00856$, maka dapat disimpulkan bahwa variabel Pajak tidak berpengaruh terhadap Transfer Pricing. Sedangkan variabel mekanisme bonus menunjukan bahwa Transfer Pricing sebesar prob. $0.5363>0.05$. Nilai kofisien yang dimiliki sebesar 0.122389 . dan dari hasil pengujian secara parsial nilai t hitung peroleh t hitung $0.623672<\mathrm{t}$ table ( 2.00856), maka dapat disimpulkan bahwa hal ini variabel mekanisme bonus tidak berpengaruh terhadap Transfer Pricing.Namun, hasil penelitian ini sama dengan Mispiyanti (2015) dan Pramana (2014) yang menemukan bahwa mekanisme bonus tidak berpengaruh terhadap Transfer Pricing.Kemudian variabel exchange rate menunjukan bahwa nilai Transfer Pricing sebesar prob. $0.0029<0.05$. Nilai Kofiesien yang dimiliki sebesar 0.475662. dan hasil dari pengujian secara parsial nilai t hitung $-2.481295>t$ tabel (2.00856), maka dapat disimpulkan bahwa hal ini variabel exchange rate berepngaruh terhadap Transfer Pricing.

\section{KESIMPULAN}

Berdasarkan kesimpulan yang dapat diambil dari penelitian ini adalah sebagai berikut:

1. Berdasarkan hasil uji hipotesis secara parsial Pajak tidak berpengaruh terhadap Transfer Pricing.

2. Berdasarkan hasil uji hipotesis secara parsial Mekanisme Bonus tidak berpengaruh terhadap Transfer Pricing.

3. Berdasarkan hasil uji hipotesis secara parsial Exchange Rate berpengaruh terhadap Transfer Pricing.

4. Berdasarkan uji hipotesis secara simultan Pajak, Mekanisme Bonus, Exchange Rate berpengaruh terhadap Transfer Pricing.

\section{Keterbatasan}

1. Terbatasnya variabel-variabel yang digunakan pada penelitian ini, seperti pajak, mekanisme bonus, exchange rate saja. Sedangkan ada variabel independent lain yang mungkin berpengaruh terhadap transfer pricing yang dapat digunakan dalam penelitian ini.

2. Sulitnya menggunakan aplikasi Eviews 9 dikarenakan banyak menu yang tidak lengkap jadi mempersulit untuk mengolah data.

3. Data penelitian ini terbatas pada periode $2016-2020$

\section{REFERENCES}

[1] Anita, W, I (2016). Pengaruh Pajak, Kepemilikan Asing,Bonus Plan dan Debt Covenant Terhadap 
Keputusan Perusahaan Manufaktur Untuk Melakukan Transfer Pricing. Universitas Budi Luhur,3(9).

[2] Arie , F dan Moch Dody (2012). Ekonometrika Esensi dan Aplikasi dengan Menggunakan EVIEWS. Jakarta : Erlangga.

[3] Avita Nia Ningsih, Wiwit Irawati, Harly Barly dan Angga Hidayat (2020) Analisis Karakteristik Aset Tetap dan Konvservatisme Akuntansi terhadap Tax Avoidance. Eko Prenuer, Jounarnal Universitas Pamulang. Vol. No.2 Juny 2020. E-ISSN: 2716- 2869 P-ISSN: 2716-2850

[4] Baiq Fitri Arianti (2020) Pengaruh Ukuran perusahaan, Financial Distress dan Audit Complexity terhadap Audit Report Lag. Gorontalo Accounting E-Journal Vol.4 No.1 April 2021 P-ISSN: 24162074 E-ISSN: 2614-2066 Nationally Accredited Journal, Decree No.36/E/KTP/2019.

[5] Darma, S. S. (2020). PENGARUH PAJAK, EXCHANGE RATE, TUNNELING INCENTIVE DAN BONUS PLAN TERHADAP TRANSAKSI TRANSFER PRICING PADA PERUSAHAAN MULTINASIONAL STUDI EMPIRIS PADA PERUSAHAAN MANUFAKTUR YANG TERDAFTAR DI BEI TAHUN 2014-

[6] 2017. Jurnal Ekonomi Efektif, 2(3).

[7] Endang Ruhiyat, Saripah Verawati. Studi Fenomenologis Penagihan Pajak Penghasilan 21 Terhadap Penerimaan Pajak Kantor Pelayanan Pajak Pratama Kebayoran Baru Dua Jakarta Selatan. Jurnal Ilmiah Akuntansi Universitas Pamulang Vol.1 No. 1, Hal: 34-42 (2013).

[8] Ghozali, Imam (2013). Aplikasi Analisis Multivariate dengan Program IBM SPSS 21 Update PLS Regresi. Semarang: Badan Penerbit Universitas Diponegoro.

[9] Gresia, M, P, dan James, T (2018). Pengaruh Pajak,Tunneling Incentive dan Mekanisme Bonus Pada Keputuan Transfer Pricing Perusahaan Manufaktur yang Terdaftar Di Bursa Efek Indonesia. Jurnal Ekonomi- Manajemen-Akuntansi 1(16), 47-56.

[10] Gusti, A, R, S, S dan I Ketut, S (2017). Pengaruh Pajak,Mekanisme Bonus, dan Tunneling Incentive Pada Indikasi Melakukan Transfer Pricing. E -Jurnal Universitas Udayana 19.2, 1000-1029. 